\title{
Effect of Alloying Element on Si Phase Precipitation from Si-Supersaturated $\alpha$-Al Solid Solution in JIS ADC12 Alloy Die Castings during Heat Treatment*1
}

\author{
Shuxin Dong*2, Yasushi Iwata, Jun Yaokawa, Kazuma Hibi and Keiichiro Oh-ishi \\ Toyota Central R\&D Labs Inc., Nagakute 480-1192, Japan
}

The growth of aluminum alloy die castings can be eliminated with a suitable heat treatment. To elucidate the parameters affecting the heat treatment conditions, we investigated the effects of alloying elements on the precipitation behavior of supersaturated silicon in die castings during heat treatment using JIS ADC12 alloy (hereafter, referred to as ADC12 alloy) and Al-11 mass\%Si alloy, considering that the former contains several alloying elements while the latter no other elements except for silicon.

Most of the supersaturated silicon in ADC12 alloy die castings precipitated with a short time heat treatment, resulting in a large number of fine silicon precipitates dispersed in the primary aluminum phase. However, the supersaturated silicon in Al-11Si alloy die castings needed a long time of heat treatment to precipitate and resulted in fewer and larger silicon precipitates in the primary aluminum phase than that of ADC12 alloy die castings. The concentration of magnesium, copper and silicon etc. was analyzed in the silicon particle near the interface with aluminum matrix in ADC12 alloy die castings using a three dimensional atom probe. These alloying elements of magnesium, copper, etc. are considered to have formed clusters suitable as the nucleuses of silicon precipitation during die casting or at the early stage of heat treatment thus promoting the precipitation of the supersaturated silicon during heat treatment.

To confirm this assumption, we examined the growth behavior of the die castings of Al-11Si alloy with an addition of magnesium. The growth of the die castings with magnesium addition was faster than that of Al-11Si alloy die castings during heat treatment, and the promoting effect of magnesium was verified on the precipitation of the supersaturated silicon in ADC12 alloy die castings. Therefore, the presence and the content of alloying elements such as magnesium, copper, etc. should be considered when deciding the heat treatment conditions for removing the growth of the die castings of Al-Si system alloys. [doi:10.2320/matertrans.F-M2019830]

(Received April 9, 2019; Accepted June 3, 2019; Published July 5, 2019)

Keywords: die casting, dimensional precision, growth, precipitation, heat treatment

\section{Introduction}

Die casting is used extensively in manufacturing automotive parts and other mechanical components because of its excellent ability to efficiently produce castings of high dimensional precision. To improve the quality of die castings, many studies have been conducted on the formation of various casting defects. ${ }^{1-4)}$ In addition to producing defectfree components, maintaining the dimensional precision of die castings at high temperatures is also required with the extension of their applications to the parts with sliding surfaces for use at high operation temperatures. However, alloying elements in die castings tend to supersaturate due to the rapid solidification and then precipitate under high temperature operation conditions, causing dimensional change, termed growth. ${ }^{5)}$ For example, a growth of more than $0.1 \%$ can be brought about by the precipitation of supersaturated elements for $\mathrm{ADC} 12$ aluminum alloy die castings. Moreover, the precipitation of the supersaturated silicon has been revealed as the primary cause for the growth. ${ }^{5)}$

Assembled die-cast parts with sliding surfaces will strain and suffer from issues like uneven wear if growth occurs during operation. Therefore, it is necessary to precipitate the supersaturated silicon after casting by heat treatment to prevent the growth of such parts during operation. ${ }^{5-7)}$ Since the precipitation of supersaturated silicon during heat treatment may be influenced by the presence of alloying elements like magnesium and copper, ${ }^{8)}$ elucidating the effects

\footnotetext{
${ }^{* 1}$ This Paper was Originally Published in Japanese in J. JFS 90 (2018) 697 702 .

${ }^{* 2}$ Corresponding author, E-mail: dongs@mosk.tytlabs.co.jp
}

of these elements is required for designing the most effective and efficient heat treatment conditions.

In this study, the effect of alloying elements on the precipitation of supersaturated silicon was investigated by examining the growth behavior of die castings made of JIS ADC12 alloy and Al-11\%Si alloy which contained no other alloying element than silicon.

\section{Experimental Procedure}

\subsection{Specimen preparation}

Die castings shown in Fig. 1 were prepared and specimens with dimensions of $6 \mathrm{~mm} \times 10 \mathrm{~mm} \times 30 \mathrm{~mm}$ were cut at the positions illustrated by the dotted lines for evaluating the growth. The surfaces of the specimen were polished with 400
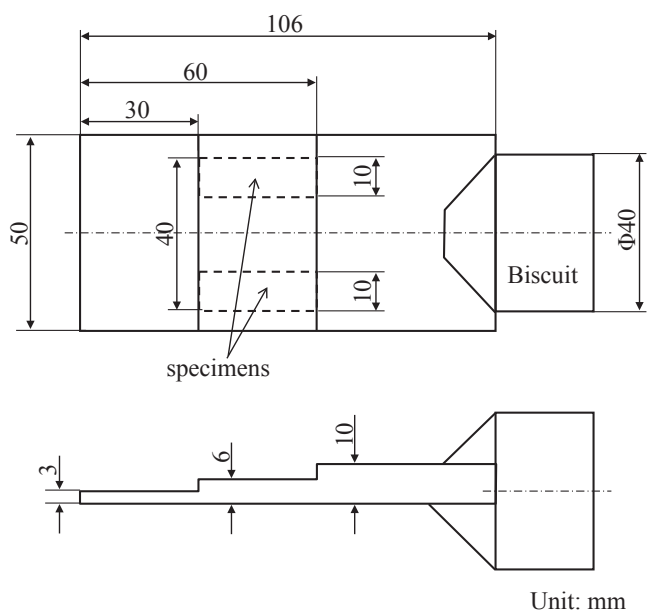

Fig. 1 Die castings for growth measurement 
Table 1 Chemical composition of alloys used for this research.

\begin{tabular}{c|c|c|c|c|c|c|c|c|c|c|c|c}
\hline & $\mathrm{Si}$ & $\mathrm{Fe}$ & $\mathrm{Cu}$ & $\mathrm{Mn}$ & $\mathrm{Mg}$ & $\mathrm{Cr}$ & $\mathrm{Zn}$ & $\mathrm{Ti}$ & $\mathrm{Pb}$ & $\mathrm{Ni}$ & $\mathrm{Sn}$ & $\mathrm{Al}$ \\
\hline $\mathrm{ADC} 12$ & 11.02 & 0.85 & 2.06 & 0.31 & 0.28 & 0.05 & 0.92 & 0.04 & 0.05 & 0.04 & 0.03 & Bal. \\
\hline $\mathrm{Al}-11 \mathrm{Si}$ & 11.02 & 0.12 & 0.01 & - & - & - & - & 0.01 & - & - & - & Bal. \\
\hline $\mathrm{Al}-11 \mathrm{Si}-0.3 \mathrm{Mg}$ & 11.02 & 0.12 & 0.01 & - & 0.29 & - & - & 0.01 & - & - & - & Bal. \\
\hline
\end{tabular}

Table 2 Die casting conditions used for this research.

\begin{tabular}{c|c}
\hline Process parameters & Conditions \\
\hline Molten metal temperature $(\mathrm{K})$ & 913 \\
\hline Injection velocity $\left(\mathrm{m} \cdot \mathrm{s}^{-1}\right)$ & 1.0 \\
\hline Pressure of plunger $(\mathrm{MPa})$ & 60 \\
\hline Mold temperature $(\mathrm{K})$ & 298 \\
\hline
\end{tabular}

grit emerypaper prior to density measurements or heat treatment. Experiments were carried out with two specimens for each of the experimental conditions. The alloy compositions and the die casting conditions used in this study are summarized in Tables 1 and 2, respectively.

\subsection{Heat treatment}

The heat treatment temperature was $473 \mathrm{~K}$ for chosen durations of $0,20,30,60,120,480$, and $900 \mathrm{~min}$. The prepared specimens were introduced into a furnace preset at $473 \mathrm{~K}$ and kept for the chosen duration of the heat treatment before being taken out and cooled to room temperature. Then, its density was calculated using Archimedes' principle employing weights measured in air and water. The same specimen was used repeatedly for heat treatment and density measurements to obtain the densities for all of the heat treatment durations.

\subsection{Calculation of growth}

The growth of specimens was calculated by using the densities noted for the as-cast state and after heat treatment for a given duration and the following equation (eq. 1).

$$
\text { Growth }=\left(\left(\rho_{\mathrm{C}} / \rho_{\mathrm{HT}}\right)^{1 / 3}-1\right) \times 100 \%
$$

Where $\rho_{\mathrm{C}}$ and $\rho_{\mathrm{HT}}$ are the density in the as-cast state and that obtained after heat treatment for a given duration, respectively.

\subsection{Analyses of structures and compositions}

The structures and compositions of the specimens were determined by optical microscopy (OM), scanning electron microscopy (SEM), transmission electron microscopy (TEM), and a three-dimensional atom probe (3DAP). OM and SEM observations were conducted for cross sections

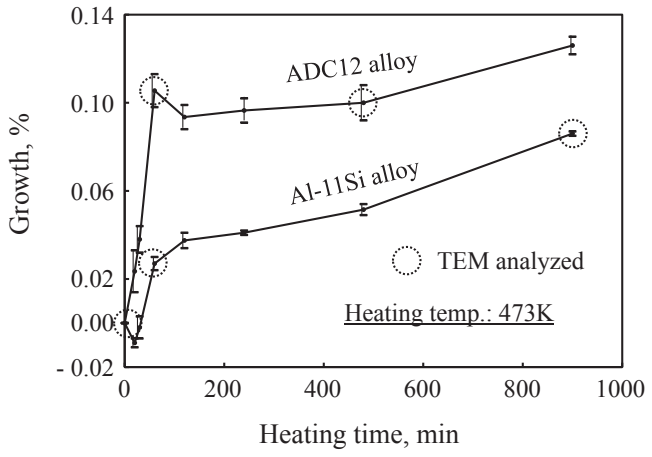

Fig. 2 Relation between heating time and growth of ADC12 alloy and Al-11Si alloy die castings.

parallel to the $6 \mathrm{~mm} \times 10 \mathrm{~mm}$ section after mirror polishing. The thin film samples for the TEM analyses were cut from the mirror-polished cross sections using a focused ion beam equipment by the micro-sampling method. In the TEM analysis, scanning transmission electron microscopy-energy dispersive X-ray spectrometry (STEM-EDX) analysis was also carried out. Some of the samples were also analyzed using a TEM equipped with a high sensitivity EDX detector. 3DAP analyses were carried out using a laser with a wavelength of $355 \mathrm{~nm}$ and energy of $35 \mathrm{pJ}$ at a sample temperature of $30 \mathrm{~K}$.

\section{Results and Discussion}

\subsection{Growth of ADC12 alloy and Al-11Si alloy die castings}

The relationship between the growth and the heat treatment time for ADC12 alloy and $\mathrm{Al}-11 \mathrm{Si}$ alloy die castings is shown in Fig. 2. For ADC12 alloy die castings, the growth increased rapidly to $0.1 \%$ in 60 minutes from the beginning of the heat treatment, but subsequently the rate of growth slowed down and only led to a further increase of about $0.02 \%$ in the following 840 minutes of the heat treatment. This growth behavior of ADC12 alloy die castings is in accordance with previous reports. ${ }^{5)}$ For Al-11Si alloy die castings, rapid growth was also observed for the first 60 minutes, but was only $0.03 \%$ in 60 minutes and continued to rise gradually afterwards to give an increase of more than $0.06 \%$ in the following 840 minutes. In other words, for Al-11Si alloy die castings, although the growth rapidly increased at the beginning of the heat treatment, the increase was small and most of the growth occurred in the following long duration of the heat treatment. 


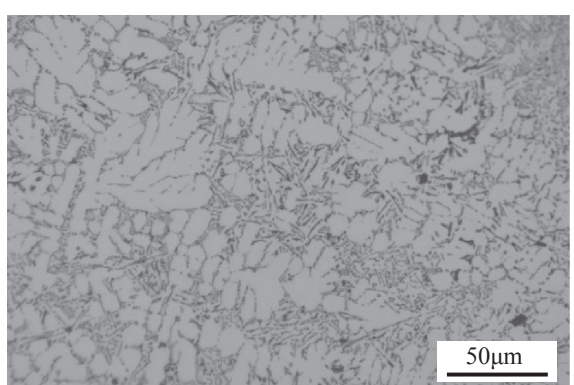

$\mathrm{ADC} 12$

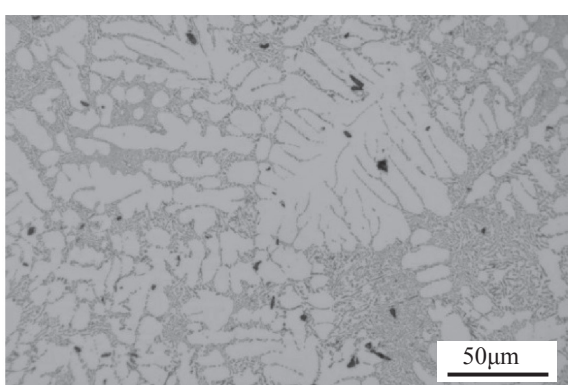

$\mathrm{Al}-11 \mathrm{Si}$

Fig. 3 Solidification structures of ADC12 alloy and Al-11Si alloy die castings.

The growth of ADC12 alloy die castings was almost complete in the first 60 minutes (one hour) of heat treatment at $473 \mathrm{~K}$. Since the growth (precipitation of silicon) of Al$11 \mathrm{Si}$ alloy die castings needed prolonged heat treatment, the presence of other alloying elements was considered to play a significant role in the precipitation of the supersaturated silicon. As observed in Fig. 2, the growth of Al-11Si alloy die castings showed a decrease of about $0.01 \%$ in 30 minutes from the beginning of the heat treatment and that of the ADC12 alloy die castings showed a little decrease between 60 minutes and 120 minutes from the beginning of the heat treatment. These changes, which may have risen from measurement errors or phase transformations and require further investigation, but have been neglected in this work because of their negligible values compared to the total growth.

\subsection{Precipitation behavior of supersaturated silicon in ADC12 alloy and Al-11Si alloy die castings}

In order to reveal the difference between the growth of ADC12 alloy and Al-11Si alloy die castings, their solidification structures were examined at first, as shown in Fig. 3. Although each structure contained dendrites of the primary aluminum phase and the eutectic structures (eutectic aluminum phase and silicon phases), Al-11Si alloy die castings showed a finer eutectic structure and a higher area fraction of the primary aluminum phase than those of ADC12 alloy die castings. In addition, several compounds were found near the eutectic structure of ADC12 alloy die castings due to its multiple constituent elements. EDX analysis results for the specimens are illustrated in Fig. 4. Besides the primary aluminum phase $(\alpha-\mathrm{Al})$ and the eutectic phase, $\mathrm{Mg}_{2} \mathrm{Si}, \mathrm{Al}-\mathrm{Cu}(-\mathrm{Mg})$ system compounds, and Al-Fe-Mn-Si system compounds were identified.

As most of the growth resulted from the precipitation of the supersaturated silicon, ${ }^{5}$ ) the specimens marked by the circle in Fig. 2 were analyzed by STEM-EDX; these were the as-cast, 60-min-heat-treated, and 480-min-heat-treated specimens for ADC12 alloy die castings and the as-cast, 60-minheat-treated, and 900-min-heat-treated specimens for Al-11Si alloy die castings. The silicon maps obtained by STEM-EDX analyses are shown in Fig. 5. In the as-cast state, i.e., before heat treatment, there was almost no concentrated silicon in the primary aluminum phase for both ADC12 alloy and Al$11 \mathrm{Si}$ alloy die castings. The two regions of concentrated silicon observed in the map of the as-cast ADC12 alloy die castings were regarded as precipitates formed during

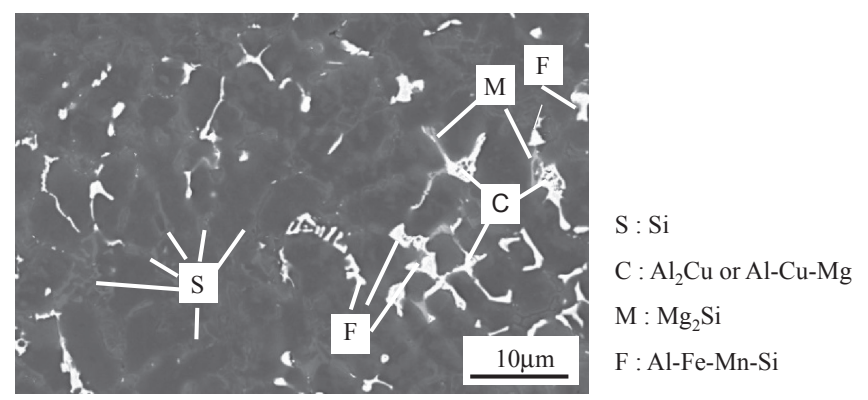

Fig. 4 Backscattered electron image of the Solidification structures of ADC12 alloy die castings.

solidification and cooling. After the first hour of the heat treatment, many small regions of concentrated silicon appeared in the primary aluminum phase of ADC12 alloy die castings, but few such regions appeared in the primary aluminum phase of Al-11Si alloy die castings. Therefore, it can be considered that most of the supersaturated silicon in the primary aluminum phase of ADC12 alloy die castings precipitated as fine particles, resulting in the rapid and large growth in the first hour of the heat treatment, but only a small part of the supersaturated silicon in the primary aluminum phase of Al-11Si alloy die castings did. The precipitation of a small part of the supersaturated silicon was considered to have contributed to the rapid growth of $0.03 \%$ for $\mathrm{Al}-11 \mathrm{Si}$ alloy die castings in the first hour of the heat treatment. In view of the small number of precipitates formed in the case of Al-11Si alloy die castings, precipitation of the supersaturated silicon in the eutectic aluminum phase was presumed to have contributed to the growth of $0.03 \%$. The supersaturated silicon in the eutectic aluminum phase was considered to have precipitated directly on the eutectic silicon phase without nucleation because of the short distance between the eutectic aluminum phase and the eutectic silicon phase. This precipitation of the supersaturated silicon in the eutectic aluminum phase was also considered to have occurred in the first hour of the heat treatment for ADC12 alloy die castings. Moreover, since no significant growth was noted after the first hour of the heat treatment for ADC12 alloy die castings, formation of supersaturated silicon in the eutectic aluminum phase was inferred to be almost complete in the first hour of heat treatment.

After 8 hours of heat treatment, the silicon precipitates in the primary aluminum phase coarsened or extended in platelike shapes for ADC12 alloy die castings, possibly owing to 

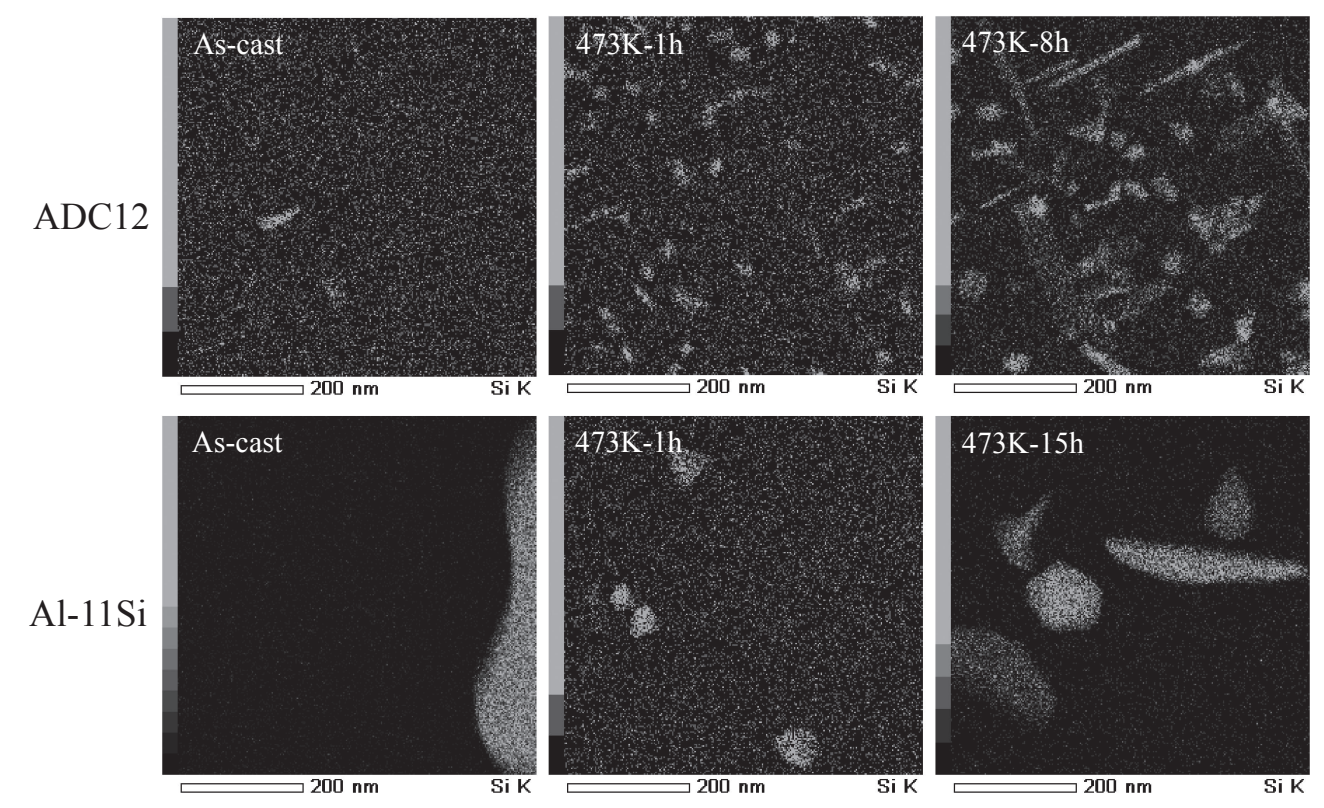

Fig. 5 STEM-EDX maps of Si in as-cast and heat treated ADC12 alloy and Al-11Si alloy die castings.

Ostwald ripening 9 ) in which comparatively small silicon precipitates disappear and silicon atoms diffuse to form large and coarse precipitates. In this coarsening process, since little supersaturated silicon precipitates, the growth increases only slightly.

On the contrary, for Al-11Si alloy die castings, even after 15 hours' heat treatment, the number of the precipitates hardly increased and the size of the precipitates enlarged by several times instead, which could be attributed to the degree of difficulty of nucleation of silicon in the primary aluminum phase of Al-11Si alloy die castings as few heterogeneous nucleation sites were present for the precipitation of the supersaturated silicon since there was no other element except for silicon. Thus, precipitation of the supersaturated silicon in the primary aluminum phase of Al-11Si alloy die castings was considered much easier by diffusion to the existing precipitates than by homogeneous nucleation itself, which requires a much higher activation energy than heterogeneous nucleation. Since the precipitates in the primary aluminum phase of $\mathrm{Al}-11 \mathrm{Si}$ alloy die castings were fewer in number, a long time was required for the supersaturated silicon atoms to diffuse to the precipitates because of the large spaces between the precipitates. Accordingly, a long time was necessary for Al-11Si alloy die castings to undergo complete growth as shown in Fig. 2.

From the above results and discussion, the difference between the growth behavior of ADC12 alloy and Al-11Si alloy die castings can be suggested to arise from the degree of ease nucleation of silicon in the primary aluminum phases. Therefore, in order to examine the factors affecting the nucleation of the supersaturated silicon in the primary aluminum phase, the correlation between silicon and other elements such as copper was investigated using TEM equipped with high sensitivity EDX detector.

The STEM-EDX maps of silicon and other elements in the primary aluminum phase of ADC12 alloy die castings heattreated for one hour at $473 \mathrm{~K}$ are shown in Fig. 6. In addition to silicon, regions of concentrated copper and magnesium were also observed. The superposed STEM-EDX map of silicon, copper, and magnesium is shown in Fig. 7. On comparing Fig. 6 and Fig. 7, magnesium was found to have concentrated along certain orientations together with silicon in the latter case. Moreover, the presence of $\mathrm{Al}-\mathrm{Cu}$ and $\mathrm{Mg}-\mathrm{Si}$ was also confirmed in and around silicon precipitates. Therefore, the precipitation of the supersaturated silicon was supposed to have been affected by the presence of copper and magnesium.

To further examine the correlation between the silicon precipitates and copper and magnesium, the silicon precipitates in the primary aluminum phase of ADC12 alloy die castings heat treated for one hour at $473 \mathrm{~K}$ were investigated in detail by 3DAP and the result is shown in Fig. 8. Two kinds of precipitates, called precipitate 1 and precipitate 2 , were observed in the primary aluminum phase. Precipitate 1 was mainly composed of silicon, with magnesium and copper concentrated in the periphery area. Precipitate 2 was a compound containing silicon, magnesium, and copper. The atom maps and concentration profiles of silicon, magnesium, and copper in the selected analysis volume of precipitate 1 shown in Fig. 9(a) are given in Fig. 9(b) and Fig. 9(c), respectively. Precipitate 1 was a silicon precipitate and some magnesium and copper atoms at concentrations of up to 10 at $\%$ segregated at the interface with the aluminum matrix. The atom maps and concentration profiles of silicon, magnesium, and copper in the selected analysis volume of precipitate 2 shown in Fig. 10(a) are given in Figs. 10(b) and 10 (c). Precipitate 2 was a compound composed of aluminum, silicon, magnesium, and copper. The compositions of the primary aluminum matrix, precipitate 1 , and precipitate 2 determined by 3DAP are given in Table 3. The primary aluminum matrix and precipitate 1 showed an almost pure aluminum phase and a pure silicon phase, respectively. Precipitate 2 was supposed to be a $\mathrm{Q}^{\prime}\left(\mathrm{Al}_{3} \mathrm{Mg}_{9} \mathrm{Si}_{7} \mathrm{Cu}_{2}\right)$ phase. $^{10,11)}$

Since the presence of copper and magnesium in the periphery of the silicon precipitate was confirmed, these 

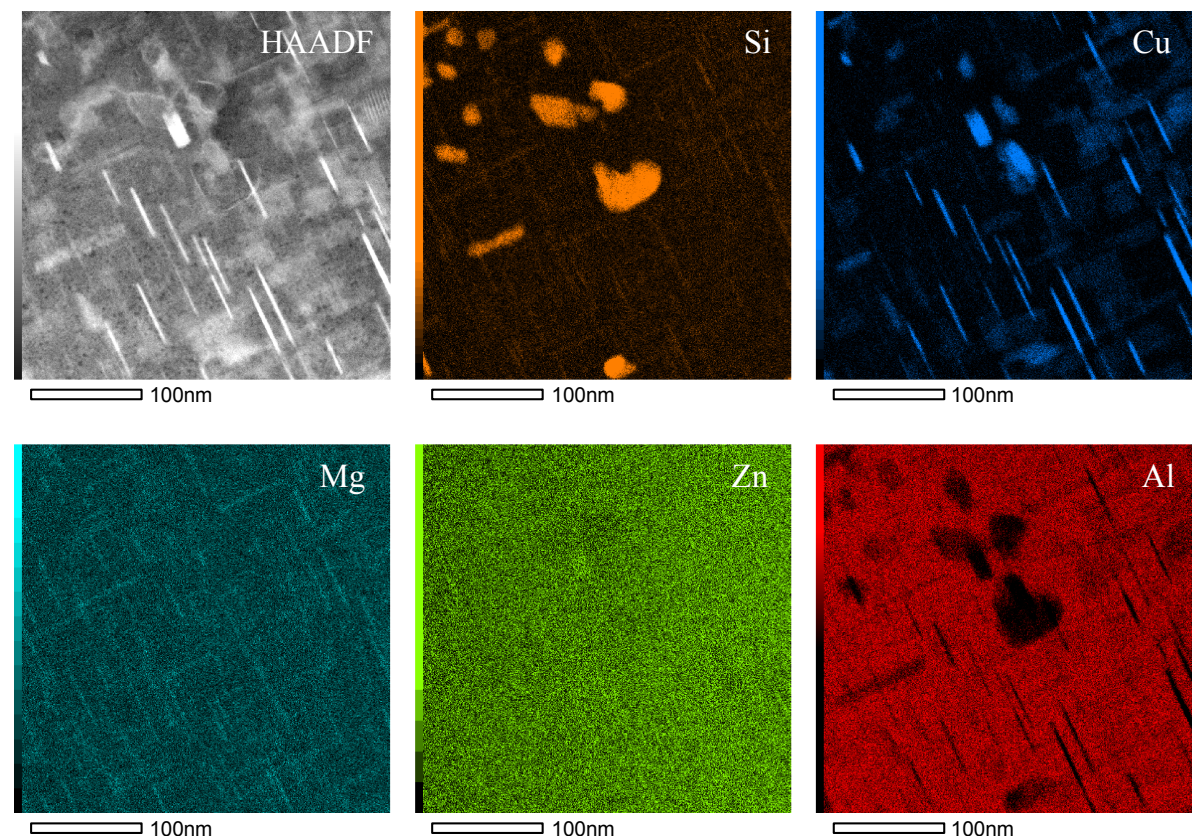

Fig. 6 STEM-EDX maps of elements in ADC12 alloy die castings heat treated at $473 \mathrm{~K}$ for 1 hour.

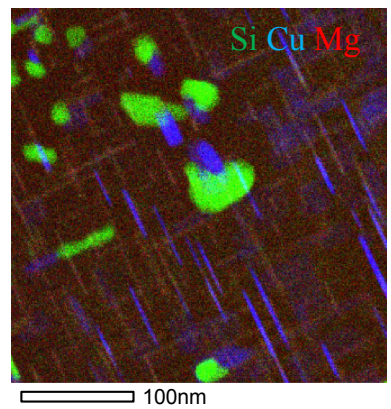

Fig. 7 Superposition of $\mathrm{Si}, \mathrm{Cu}$ and $\mathrm{Mg}$ STEM-EDX maps in ADC12 alloy die castings heat treated at $473 \mathrm{~K}$ for 1 hour.
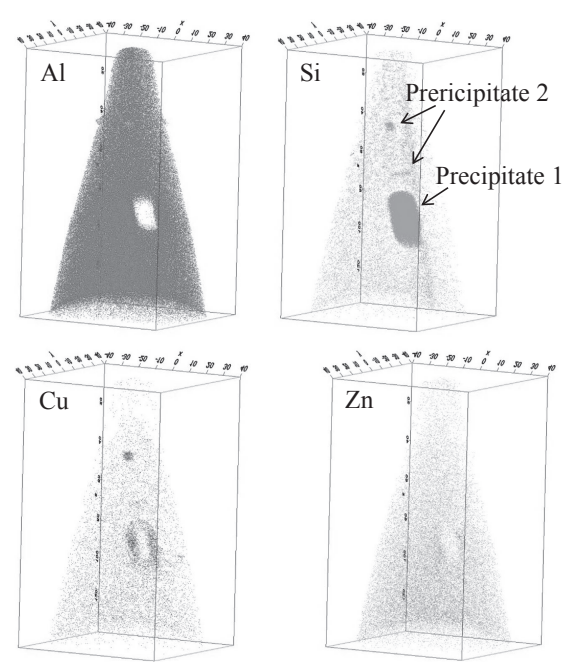

Fig. 8 3DAP elemental maps of ADC12 alloy die castings heat treated at $473 \mathrm{~K}$ for 1 hour.

elements were inferred to have been related to the precipitation of the supersaturated silicon in the primary aluminum phase. Moreover, as much higher amount of precipitates were observed for the primary aluminum phase $\underline{30 \mathrm{~nm}}$

(a)
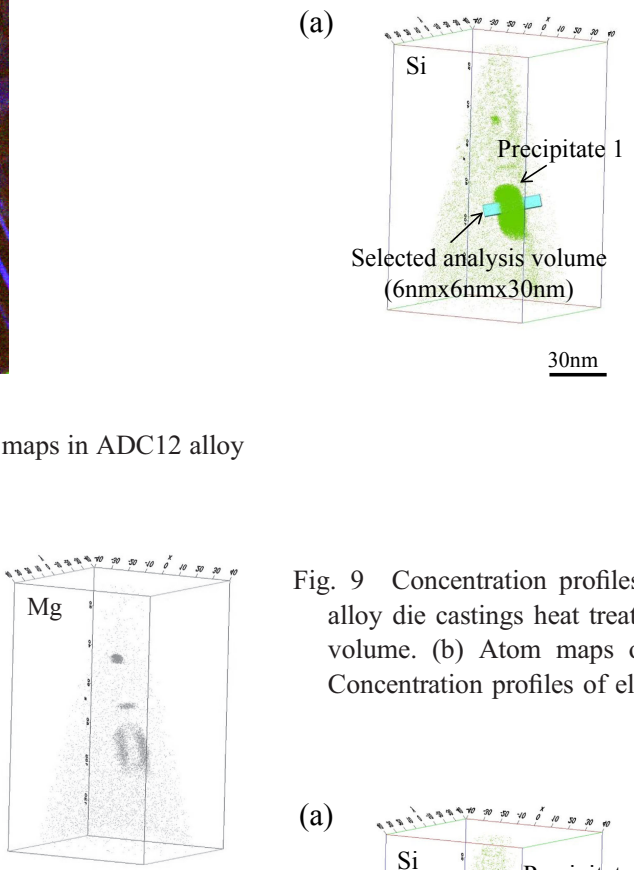

(a)

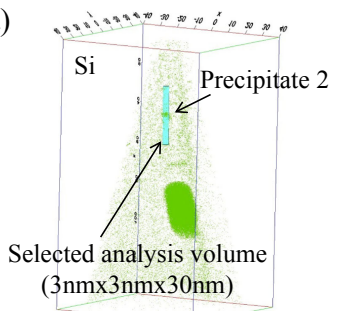

$\underline{30 \mathrm{~nm}}$ (b)

(c)

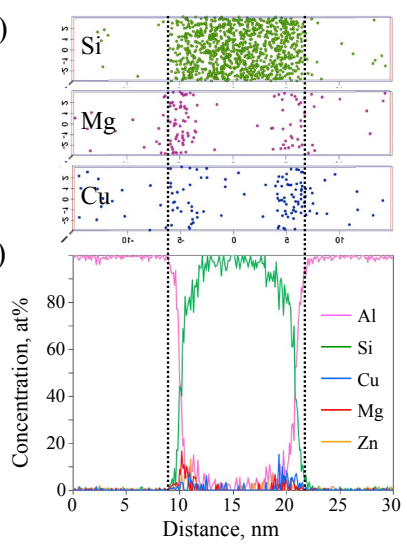

Fig. 9 Concentration profiles of elements along precipitate 1 in $\mathrm{ADC} 12$ alloy die castings heat treated at $473 \mathrm{~K}$ for 1 hour. (a) Selected analysis volume. (b) Atom maps of $\mathrm{Si}, \mathrm{Mg}$ and $\mathrm{Cu}$ in selected volume. (c) Concentration profiles of elements in selected volume.

(b)

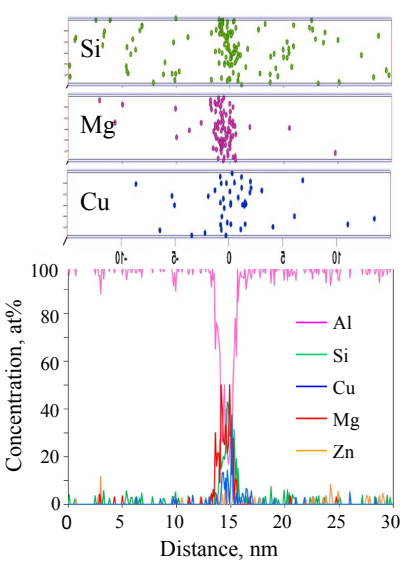

Fig. 10 Concentration profiles of elements along precipitate 2 in ADC12 alloy die castings heat treated at $473 \mathrm{~K}$ for 1 hour. (a) Selected analysis volume. (b) Atom maps of $\mathrm{Si}, \mathrm{Mg}$ and $\mathrm{Cu}$ in selected volume. (c) Concentration profiles of elements in selected volume. 
Table 3 Composition of matrix and precipitates calculated from measurement results by 3 DAP.

\begin{tabular}{c|c|c|c}
\hline & \multicolumn{3}{|c}{ Composition (at\%) } \\
\hline Elements & Matrix & Precipitate 1 & Precipitate 2 \\
\hline $\mathrm{Al}$ & 99.1 & 2.1 & 28.6 \\
\hline $\mathrm{Si}$ & 0.3 & 96.9 & 31.0 \\
\hline $\mathrm{Mg}$ & 0.1 & 0.2 & 29.5 \\
\hline $\mathrm{Cu}$ & 0.1 & 0.4 & 8.6 \\
\hline $\mathrm{Zn}$ & 0.4 & 0.4 & 2.3 \\
\hline
\end{tabular}

of ADC12 alloy die castings heat treated for one hour than for Al-11Si alloy die castings, copper and magnesium were considered to offer a promoting effect on the nucleation of supersaturated silicon in the primary aluminum phase.

In $\mathrm{Al}-\mathrm{Mg}-\mathrm{Si}$ alloys, known as 6000 series aluminum alloys, $\mathrm{Mg}-\mathrm{Si}$ clusters have been reported to form during preaging and have a promoting effect on the precipitation of the intermediate phases of the $\beta$ phase, i.e. $\beta^{\prime \prime}$ and $\beta^{\prime}$ phases, by providing nucleation sites. ${ }^{12-14)}$ Although a detailed mechanism for such processes is still needed, it is also possible in this study that the supersaturated silicon started to precipitate on some crystal faces of $\mathrm{Mg}-\mathrm{Si}$ clusters. At the same time, magnesium and copper may have also diffused to silicon precipitates to form compounds on the surface of the silicon precipitate. The excessive silicon not required for the formation of compounds probably diffused further into the inner region of the precipitate to contribute to the amount of the precipitate.

In order to confirm the presumed promoting effect of magnesium and copper on the precipitation of the supersaturated silicon mentioned above, the growth of Al-11Si alloy die castings was investigated by adding $0.3 \%$ magnesium to the alloy as it is an element assumed to promote the precipitation of supersaturated silicon. Since copper is a necessary alloying element for the ADC12 alloy, magnesium, an impurity element, was chosen as the additive element to examine the relation between the growth and the presence or absence of magnesium so as to verify its promoting effect. The measured growth of Al-11Si alloy die castings with and without the addition of magnesium is illustrated in Fig. 11. The growth of $\mathrm{Al}-11 \mathrm{Si}$ alloy die castings without magnesium addition was under $0.03 \%$ in the first hour of the heat treatment, but that of Al-11Si alloy die castings with an addition of $0.3 \%$ magnesium is above $0.06 \%$, i.e., the growth increased significantly on addition of magnesium. Therefore, the promoting effect of magnesium on the growth of the supersaturated silicon in the primary aluminum phase during heat treatment was demonstrated experimentally.

\section{Conclusion}

In order to elucidate the effect of alloying elements on the precipitation of supersaturated silicon from the primary aluminum phase of ADC12 alloy die castings during heat

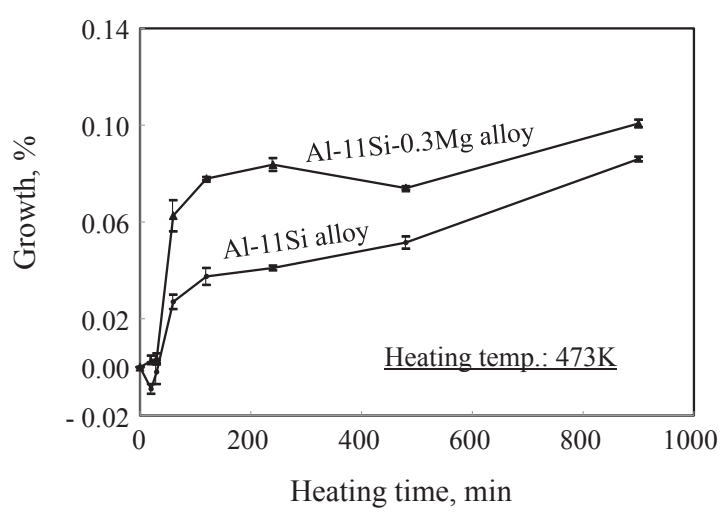

Fig. 11 Relation between heating time and growth of Al-11Si alloy and Al-11Si-0.3Mg alloy die castings.

treatment, the growth behavior and structures of $\mathrm{ADC} 12$ alloy die castings and Al-11Si alloy die castings with and without the addition of magnesium were compared and examined. The following conclusions were obtained.

(1) The supersaturated silicon in the primary aluminum phase of ADC12 alloy die castings almost completely precipitated in a short time on heat treatment. In contrast, prolonged heat treatment was necessary for the supersaturated silicon to precipitate from the primary aluminum phase of Al-11Si alloy die castings, which contained no other alloying element than silicon.

(2) After heat treatment, many fine silicon precipitates appeared in the primary aluminum phase of ADC12 alloy die castings, but only a few precipitates resulted from the Al-11Si alloy die castings. The precipitates in the primary aluminum phase of $\mathrm{Al}-11 \mathrm{Si}$ alloy die castings hardly increased in number even after prolonged heat treatment, but became coarser.

(3) Concentrated magnesium and copper could be observed near the interface between the aluminum matrix and the precipitates generated by heat treatment of the ADC12 alloy die castings.

(4) Magnesium and copper were considered to promote the precipitation of supersaturated silicon in the primary aluminum phase of ADC12 alloy die castings by providing heterogeneous nucleation sites for silicon during heat treatment.

(5) The growth of Al-11Si alloy die castings was proven to be promoted by magnesium during heat treatment.

(6) When determining the heat treatment conditions for eliminating the growth of Al-Si alloy die castings, the presence and the contents of elements such as magnesium and copper should be taken into account.

\section{REFERENCES}

1) Y. Iwata, S. Dong, Y. Sugiyama and H. Iwahori: Mater. Trans. 54 (2013) 1944-1950.

2) Y. Iwata, S. Dong, Y. Sugiyama and H. Iwahori: Mater. Trans. 55 (2014) 311-317.

3) Y. Iwata, S. Dong, Y. Sugiyama and H. Iwahori: Mater. Trans. 53 (2012) 483-488.

4) S. Dong, Y. Iwata, Y. Sugiyama and H. Iwahori: Mater. Trans. 51 (2010) 371-376.

5) S. Dong, Y. Iwata, Y. Sugiyama and H. Iwahori: Mater. Trans. 58 
(2017) 1562-1570.

6) Nihon Sougou Imono Center: Keikinzoku Imono Binran, (Maruzen Co., Ltd., Tokyo, 1965) p. 264

7) L.A. Godlewski, X. Su, T.M. Pollock and J.E. Allison: Metall. Mater. Trans. A 44 (2013) 4809-4818.

8) The Japan Institute of Light Metals: The Structures and Properties of Aluminum, (Tokyo, 1991) p. 283

9) T. Miyazaki: Materia Japan 53 (2014) 479-484.
10) A. Biswas, D. Siegel and D.N. Seidman: Acta Mater. 75 (2014) 322336.

11) J.Y. Hwang, R. Banerjee, H.W. Doty and M.J. Kaufman: Acta Mater. 57 (2009) 1308-1317.

12) K. Matsuda and S. Ikeno: J. JILM 50 (2000) 23-36.

13) K. Matsuda and S. Ikeno: J. JILM 53 (2003) 457-462.

14) H. Yang, S. Ji, W. Yang, Y. Wang and Z. Fan: Mater. Sci. Eng. A 642 (2015) 340-350. 